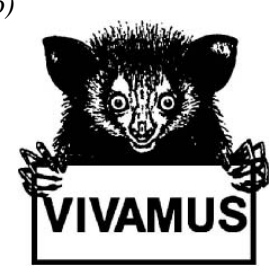

\title{
Long-term Study of Group Dynamics and Female Reproduction in Venezuelan Pithecia pithecia
}

\author{
Marilyn A. Norconk ${ }^{1,2}$ \\ Received November 19, 2004; revision February 24, 2005; accepted March 8, 2005; \\ Published Online July 6, 2006
}

White-faced sakis (Pithecia pithecia) are well known for their specialized feeding strategy and dependence on seed-eating, but we know less about social dynamics and reproduction. I summarize data from 1990 to 2001 on sakis inhabiting a small island in Lago Guri, Venezuela that includes changes in group composition, aggressive behavior, and female reproductive histories. Though the characteristic group size and typical mating system are still uncertain for wild, free-ranging Pithecia spp., size of the study group ranged from 2-3 adult females and 1-4 adult males. My group and I collected fecal samples from adult females, which we dried and assayed for estrogen $\left(E_{1} C\right)$ and progesterone $(P d G)$ conjugates to document reproductive cycles and female development. During the study, as many as 3 females were either cycling or pregnant at the same time. Ten infants were born during the study, 4 of which survived to adulthood. Five interbirth intervals after weaning an infant ranged from 12 to 36 mo. Though researchers often assume Pithecia spp. are monogamous, multiple breeding females can coexist in groups without evidence of reproductive suppression. Within the pitheciine clade, Pithecia spp. exhibit a mosaic of behavioral and morphological traits intermediate between bearded sakis and uakaris on the one hand and their sister-group, the pairbonded titis, on the other.

KEY WORDS: aggression; demography; estrone; group size; platyrrhine .

The subfamily Pitheciinae includes 3 closely related genera, Pithecia (sakis), Chiropotes (bearded sakis), Cacajao (uakaris), and their sister group, the titis (Callicebus) (Schneider and Rosenberger, 1996). Titi

\footnotetext{
${ }^{1}$ Department of Anthropology and School of Biomedical Sciences, Kent State University, Kent, Ohio.

${ }^{2}$ To whom correspondence should be addressed; e-mail: mnorconk@kent.edu.
} 
lack the signature dental traits of sakis and uakaris (procumbent highcrowned incisors and laterally splayed, robust canines: Kinzey, 1992; Martin et al., 2003), but titis share some characteristics with the smallest sakis. The lower range of body mass in Pithecia spp. (1347-3000 g; Hershkovitz, 1987a) overlaps with the upper range of Callicebus (7001605 g, Hershkovitz, 1990) Chiropotes and Cacajao larger (2500-4000 g: Hershkovitz, 1985, 1987b). Similarities in group size and behaviors related to intergroup aggression ally Pithecia with Callicebus, whereas similarities in dental structure, diet, bushy tails, and apparently low levels of paternal care unite Pithecia with Chiropotes and Cacajao (Norconk, 1997).

Hershkovitz (1987a) recognized 8 taxa (5 species) of Pithecia separated into 2 groups, the Pithecia group ( 2 subspecies) north of the Amazon River and the Monachus group ( 6 taxa in 4 species in the central and western Amazon Basin). In the only morphological study to include all members of the genus since Hershkovitz's publication, Marroig and Cheverud (2004) advocated raising the 5 western taxa to specific level (Pithecia. albicans, $P$. irrorata, $P$. vanzolinii, $P$. monachus, and $P$. aequatorialis) based on similarities in cranial morphology for a total of 6 species. However, L. K. Marsh and A. B. Rylands (pers. com.) suggest that the taxonomic arrangement may not capture the diversity of western Amazon Basin sakis. Within Pithecia spp., researchers have conducted long-term studies only on Pithecia pithecia (Cunningham, 2003; Norconk, 1996; Setz, 1993; Setz and Gaspar, 1997) with censuses or short studies on other species (Freese et al., 1982; Heymann et al., 2002; Johns, 1986; Peres, 1993; Soini, 1986).

Throughout much of their range, Pithecia are sympatric with either Chiropotes or Cacajao and-except in the Guianas where Callicebus is absent-Pithecia spp. are also sympatric with Callicebus spp. Though Pithecia is one of the most understudied genera of Platyrrhini, all species appear to share a pattern of small group size and cryptically colored females. Males exhibit a range of sexual dichromatism in facial and body pelage, strongest in Pithecia spp. (Hershkovitz, 1987a). Mild to moderate sexual dimorphism in body mass is also evident (female body mass ranges from $68 \%$ to $93 \%$ of male body mass) (Norconk, 1997). Related to their cryptic appearance and behavior, particularly females, Pithecia are one of the most difficult of the platyrrhines to habituate to human observers. Most studies of Pithecia spp. provided detailed information on feeding ecology, but fewer data exist on social behavior (Buchanan et al., 1981; Oliveira et al., 2003; Peres, 1993; Soini, 1986; Vié et al., 2001). As a result, many unresolved issues remain, including relations among adults, maturation of subadults and their relationship to their natal group, and characteristics of intergroup dynamics. Researchers are still investigating fundamental issues related to 
social behavior such as group size and composition. Small group size appears to characterize most groups of Pithecia (Lehman et al., 2001), but the designation of sakis as monogamous has crept into the literature prematurely (Buchanan et al., 1981; Robinson et al., 1987; Vié et al., 2001, cf. Fuentes, 1999; Lehman et al., 2001).

I summarize data on the social dynamics of a well-habituated group of white-faced sakis inhabiting a small island (Isla Redonda) in Lago Guri, Venezuela via data collected from 1990 to 2001. The lake formed behind the Raul Leoni dam and reached its maximum water level in 1986 (Alvarez et al., 1986). Preliminary observations and habituation began on Isla Redonda in 1989 (Homburg, 1997). Primates in the Caroní River basin (Pithecia pithecia, Alouatta seniculus, and Cebus olivaceus) probably occupied the same or nearby forest before flooding and moved uphill as lowlying habitats flooded. There was no effort to translocate sakis within the lake as flooding proceeded (L. Balbás, pers. com.).

We explored several islands in the northern part of the lake and observed groups of white-faced sakis on most of the islands. However, researchers were unable to habituate sakis on larger islands. It took almost a year of observation before it was possible to recognize and easily follow all individuals on Round Island-an area of only 11.8 ha (I. Homburg and A. Peetz, pers. com.). Despite the small size of the island, the group was not cohesive and individuals changed social allegiances several times during the study. Most individuals, regardless of age, eventually left the main group to travel alone or in small groups. Subjects expressed aggression at peripheral individuals via chasing and provided details about social strategies that researchers should examine further in free-ranging sakis. I also present data on female reproduction and development that accord well with studies of captive sakis (Savage et al., 1992, 2002; Shideler et al., 1994).

\section{METHODS}

\section{Study Site}

Flooding of the Río Caroní from 1978 to 1986 created a reservoir of $4250 \mathrm{~km}^{2}$ in eastern Venezuela and fragmented the forest of the Caroní basin into $>100$ islands (Fig. 1). Islands range from 0.25 ha to $>300$ ha (Alvarez et al., 1986; Terborgh et al., 1997). Isla Redonda $\left(7^{\circ} 46^{\prime} \mathrm{N}, 62^{\circ} 53^{\prime} \mathrm{W}\right.$ ) is a 11.8-ha hilltop completely surrounded by water and supporting a dry tropical, primarily evergreen forest (Aymard et al., 1997; Norconk and Grafton, 2002; Parolin, 1992; 1993). 


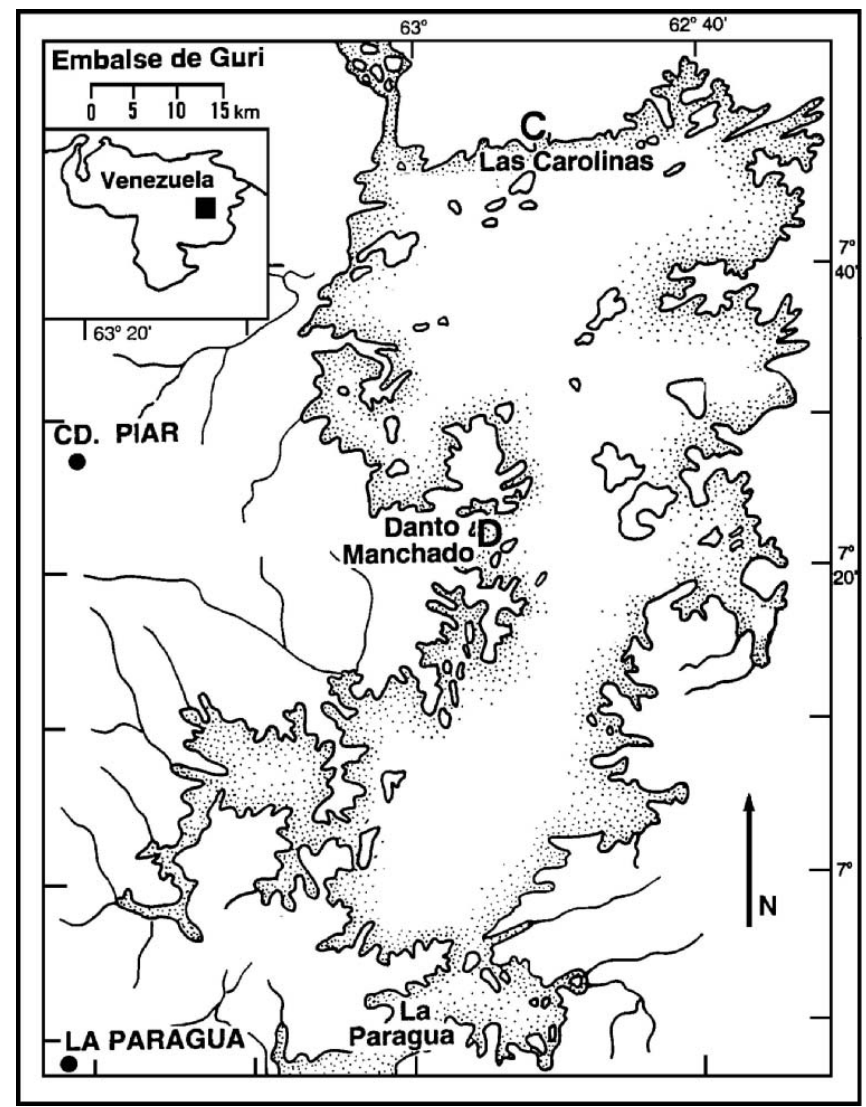

Fig. 1. Approximate location of the field site, Isla Redonda, is at the north end of the lake, in the vicinity called Las Carolinas (C). (Reprinted with permission from G. Aymard.)

Lago Guri has a single wet and a single dry season, each lasting $c a$. 6 mo (Norconk, 1996). Relatively little rain falls from November to April, with March and April in the late dry season averaging between only 20 and $35 \mathrm{~mm}$, respectively. More rain falls from May to October, with peaks in June and July $(226 \mathrm{~mm}$ and $250 \mathrm{~mm}$, respectively_averages over a 6-yr period) (CVG-EDELCA, 1997).

We conducted both short- and long-term studies on Isla Redonda from 1990 to 2001. The sakis were habituated to human observers by I. Homburg and A. Peetz in 1989 and have maintained extremely good tolerance to humans throughout the study. We identified individuals via distinctive facial or tail features and pelage color. In 
addition to unpublished personal field notes, I consulted several sources during the preparation of this paper: Brush (2000); Brush and Norconk (1999); Buzzell and Brush (2000); Ceballos (1996); Cunningham (2003); Harrison (1998); Homburg (1997); Riveros (1996); Ryan (1995); Walker (1996).

\section{Subjects}

Because we continued observations over a decade, during which many individuals changed age classes, I refer to the sakis via 2-letter names. Demographic data (birth, death, disappearance, and whether they left the main group) for each individual are in Fig. 2. We could not determine kinship of the 2 adult females (MA and US) in the group at the onset of the study. MA survived to the end of the study, and her daughter and granddaughter were

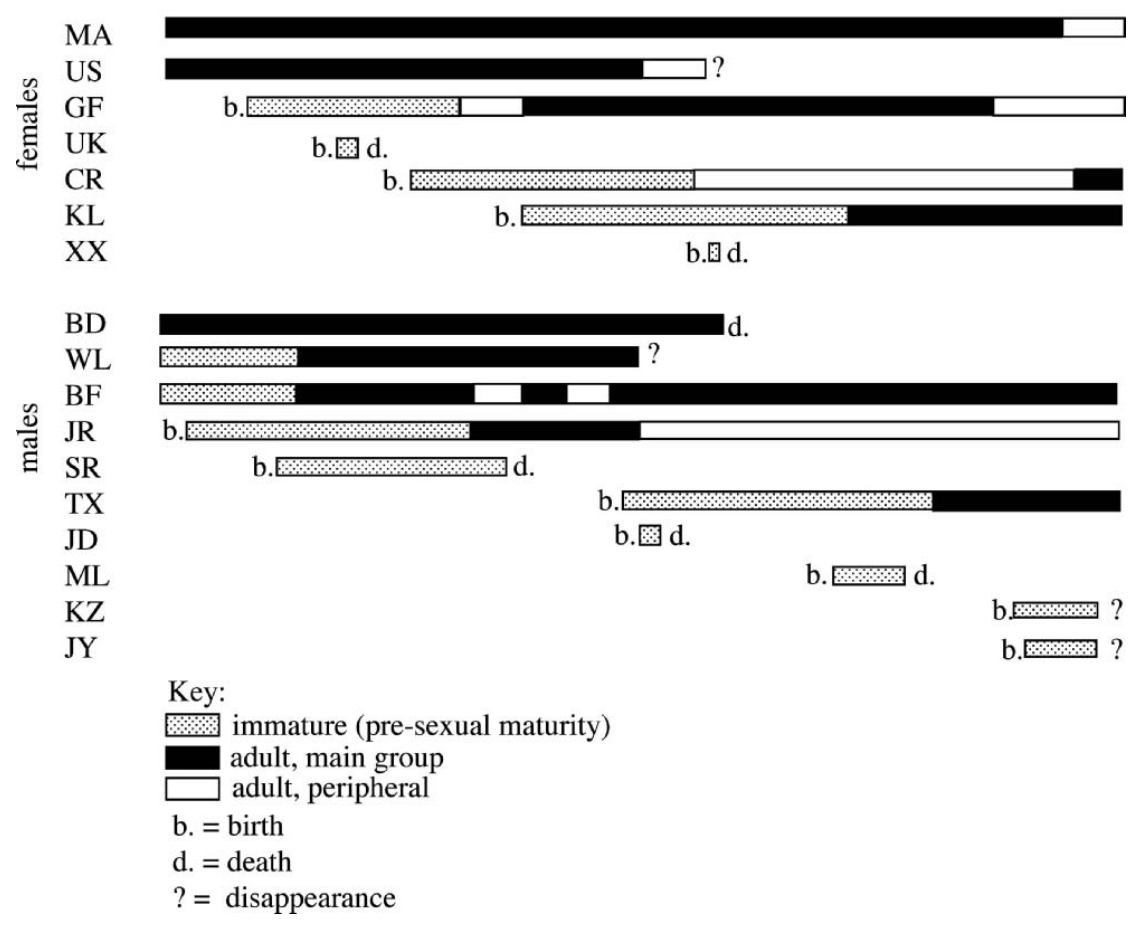

Fig. 2. Composition of the Isla Redonda group of sakis showing change in group size and composition over time including births, deaths, disappearances, and peripheralization of some individuals beginning in 1993. (Data from 1989 and 1990 are from Homburg, 1997). 
both reproductively active during the study. The genetic relationship of MA to adult and subadult males $(\mathrm{BD}, \mathrm{WL}, \mathrm{BF})$ at the onset of the study are also unknown, but the mothers of infants born during preliminary observations (1989-1991: Homburg, 1997) and subsequent to 1990 are documented (Fig. 2).

Three infant birth dates are known from observations that occurred on the birth date or shortly thereafter. For other infants, we estimated approximate birth dates based on transport position on the mother. Infants straddle the mother's thigh from birth to $c a .1$ mo and then shift to a dorsal position until about 4 mo when they gain increased locomotor independence (Savage et al., 1992). Buzzell and Brush (2000) and Homburg (1997) reported that mothers carry infants extensively in the 12th week of life, but may leave them briefly in the care of other individuals between the 9th and 12th week. Mothers left 5-mo-old infants alone to follow them and Homburg (1997) documented the onset of solitary play at this age.

At birth, males resemble adult females more closely than they do adult males in pelage color and then undergo a gradual period of color change in facial and body pelage. The transition to mature male pelage exhibits considerable individual variation in age at onset and duration. Bode (cited in Buchanan et al., 1981: 404) documented a much faster color change to the adult pattern - by 3 mo-than Homburg (1997), who reported that the transition began at $c a$. 20 mo. Subadult males retain vestiges of orange hair ventrally, under their arms and at the base of the tail, but all males exhibit uniformly black body pelage and bright white faces by $3.5-4 \mathrm{yr}$ (Norconk, 1997). We estimated female maturity based on the onset of regular ovarian cycles.

\section{Sampling Methods}

We collected behavioral and ecological data for 5-10 d/mo during 17 mo in 1991 and 1992. After 1992, annual or semiannual study periods ranged from 1 to $5 \mathrm{mo}$, with an attempt to balance data collection during wet season and dry season months each year. The focus of the long-term study was primarily ecological (Norconk, 1996; Norconk and Conklin-Brittain, 2004), but we recorded data on social interactions, particularly aggressive ones, via all-occurrence data (Altmann, 1974) for aggressive chases. We recorded time of day, individuals involved in the chase, minimum chase distance, and duration and distance of a chase. We used trail marks at 25-m intervals as reference points and calculated the distance on trail maps with a digital plan measurer. 
Peripheralization refers to the exclusion of $\geq 1$ members from the main group by other members. At the onset of the study, there was only 1 group on the island, but individuals began leaving it and either moved singly or in small groups by 1993. The subjects maintained exclusion by chasing nongroup individuals. After the 3rd year of the study, we designated subjects as either members of the main group or peripheral individuals.

We collected fecal samples from known females beginning in 1993 and continued during each data collection period. We collected early morning samples, i.e., when individuals left their sleeping trees, whenever possible, at least once every $3 \mathrm{~d}$. If we missed samples when subjects emerged from the sleeping tree, we collected them at the next opportunity. We air-dried fecal samples without preservatives on the island and stored them in sterile Whirl-pak ${ }^{\circledR}$ bags. Within $5 \mathrm{~d}$, we transported samples to base camp in the village of Guri for thorough drying in a Labline oven at $50^{\circ} \mathrm{C}$. We sent dried samples to Dr. Susan Shideler (Center for Health and the Environment, University of California, Davis, CA) for analysis. We weighed and dried samples further if necessary, and reconstituted them in solubilizing buffer. We shook the buffer solution for 24-48 h. We then centrifuged, diluted, aliquoted, and assayed the samples via enzyme immunoassay for pregnanediol-3-glucuronide (PdG) and estrone conjugate $\left(\mathrm{E}_{1} \mathrm{C}\right)$ fecal metabolites (Shideler et al., 1994). Fecal samples permitted us to document physiological events that are useful from a demographic perspective, i.e., onset of ovulatory function, pregnancy, early fetal loss, and duration of lactation. Shideler et al. (1994) and Savage et al. (1992, 2002) explicate more detailed methods and related work on the reproductive physiology and behavior of captive white-faced sakis.

\section{RESULTS}

\section{Characteristics of the Group}

Group size increased from 6 in 1989 (Homburg, 1997) to 9 in 1993, with an average of 6.7 and a mode of $6(n=12$ sample years) (Table I). In mid-1993, the group included 4 adult males (BD, WL, JR, and BF), a 2-yrold male (SR), and 3 adult females (MA, US, and GF). Individuals started leaving the group in 1993 and $\geq 1$ individuals that had been members of the main group were peripheralized, some intermittently, until the end of the study in 2001. The identity of peripheral individuals changed during the study, but the number of individuals was relatively constant, comprising 1 adult male and 1 or 2 adult females (Table I). By the end of the study, all 
Table I. Demographic characteristics of the Isla Redonda white-faced sakis from 1990 to 2001

\begin{tabular}{lccrr}
\hline \multicolumn{1}{c}{ Variable } & Average & SD & Mode & $n(\mathrm{yr})$ \\
\hline Main group size & 6.67 & 1.61 & 6 & 12 \\
Peripheral individuals & 2.33 & 0.50 & 2 & 9 \\
Number of adult males in main group & 2.42 & 0.90 & 3 & 12 \\
Number of adult females in main group & 2.33 & 0.49 & 2 & 12 \\
Annual infant death or disappearance rate & 0.42 & 0.67 & 0 & 12 \\
Annual birth rate (births/adult female/yr) & 0.36 & 0.32 & 0.5 & 12 \\
Ratio of adult males to adult females-main group & 1.06 & 0.34 & 1 & 12 \\
Ratio of males to females-main group (all ages) & 1.11 & 0.32 & 1 & 12 \\
Ratio of males to females-peripheral individuals & 0.89 & 0.22 & 1 & 9 \\
\hline
\end{tabular}

Data are compiled from all individuals on the island, those in the main group, and peripheral individuals.

adults except for 1 male and 1 female had, at one time or another, left the main group.

Of the 4 females that left the group during the study, 2 did so for the first time between 3 and $4 \mathrm{yr}$. One female (GF) left the group briefly as a young female and again at $10 \mathrm{yr}$ (Fig. 2). The 2 oldest females also left the group. We did not see female US long after she left the group and presume she died. Another female (MA) was adult at the onset of the study and the major breeding female. She left the group at $>15 \mathrm{yr}$. Of the males that left the group, BF did so briefly as a young adult (4-5 yr), then returned. JR left at $c a .5 \mathrm{yr}$ and remained a peripheral individual for the remainder of the study (Fig. 2).

The ratio of adult males to adult females in the main group is slightly skewed in favor of males (1.05; Table I). When one considers both adults and subadults, including infants and juveniles, the sex ratio is decidedly male-biased (1.11). Nevertheless, the modal number of males and females in the group over the 12-yr period is 1:1. The adult annual survival rate $(64 \%, n=12 \mathrm{yr})$ is higher than infant survival rate $(40 \%, n=$ 10 infants).

\section{Deaths and Disappearances}

Various factors caused deaths and disappearances, none of which were definitively the result of predation or genetic abnormalities related to inbreeding - the study continued $c a .15 \mathrm{yr}$ postflooding and isolation (no known immigration or emigration) was apparently complete then. Two infants and 1 male (SR) may have died from falls because we found their bodies intact and showing no evidence of marks related to predation. In 2 additional cases, the source of the falls was related to capturing/darting 
some individuals in 1996. Evident weakness (poor clinging) preceded 1 infant death and we noted an apparent incidence of fetal loss in the hormonal data. Two healthy-appearing infants (KZ and JY) disappeared while observers were absent from the study site. Two adults (WL and US) disappeared and we did not find their remains.

\section{Female Reproduction: Interbirth Intervals and Seasonality}

There were 12 births between 1989 and 2000 (GF, JR and SR were born before the onset of this study by Homburg, 1997). MA was the principle breeding female and all but 1 infant (SR) was born to her, her daughter GF, or her granddaughter KL (Fig. 2). We did not know the genetic relationship of adult males (BD, WL, and $\mathrm{BF}$ ) at the onset of the study. We detected 1 pregnancy (US) via fecal steroids (Fig. 4a), but it did not result in a live birth. MA was pregnant at the same time as US and gave birth to an infant (TX) in November, 1994 (Fig. 4b).

The average interbirth interval (IBI) after a live birth is $21.2 \mathrm{mo}$ (range 12-36 mo) (Table II). IBIs after the death of unweaned infants were not shorter than IBIs after a weaned infant, though 1 was very long (41 mo). The female may have miscarried or given birth to an infant that died while we were absent. Ten of 12 births occurred in the dry season; the modal month was January (Fig. 2, Table III). Infant deaths were split evenly between wet and dry seasons.

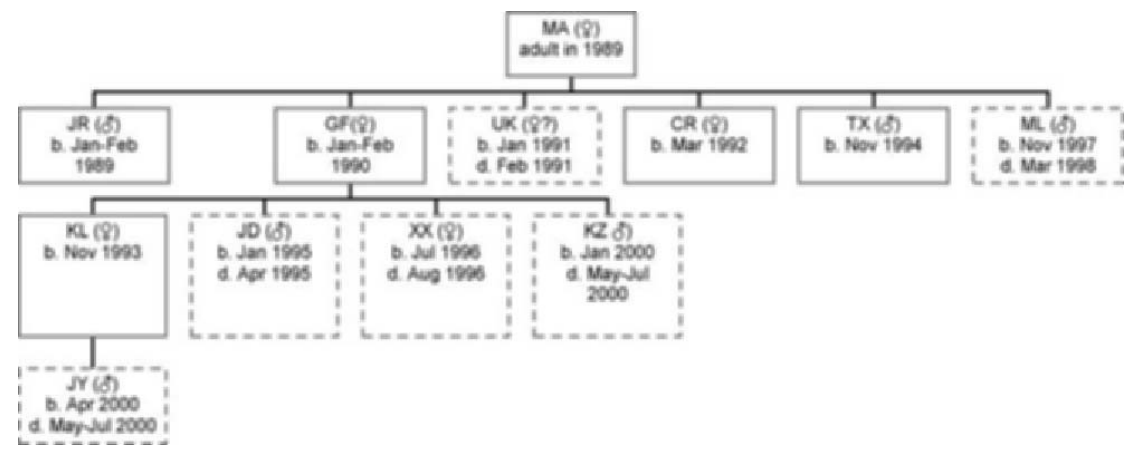

Fig. 3. Geneology of 1 adult female, MA, who was an adult at the onset of the study and survived until the end of the study. Birthdates or estimates of birthdates (b) are provided for each offspring. Death dates (d) are indicated where relevant. Solid lines = individuals that survived to the end of the study; dashed lines = individuals that died or were presumed dead during the study. (JR was born in 1998 before the study began. Data from Homburg, 1997.) 


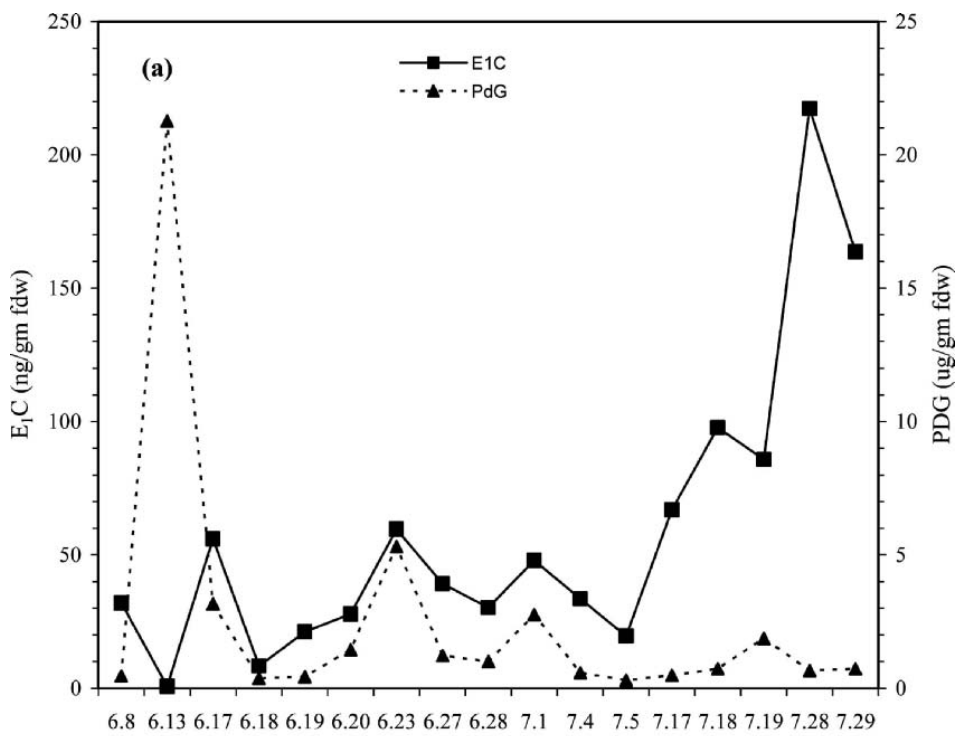

Sample date (1994)

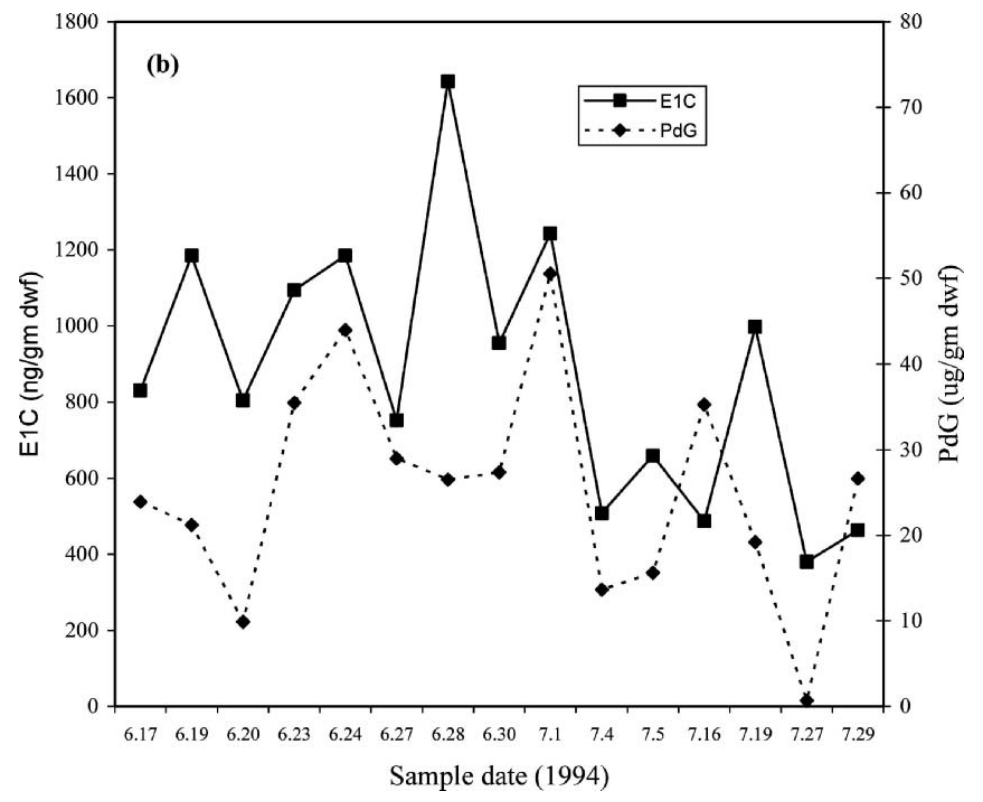

Fig. 4. Documentation of the onset of pregnancy for female US in mid-July (a). Values expressed in dry weight of feces (dwf). Pregnancy did not go to term, but was concurrent with the pregnancy of the other adult female, MA (b). (b) Copulations with BD on June 8 and 9 with subsequent early pregnancy documented. Live birth occurred in ca. mid-November (male: TX) 1994. $\mathrm{E}_{1} \mathrm{C}$ and $\mathrm{PdG}$ values expressed in dwf. 
Table II. Inter-birth intervals (IBI) for after weaning an offspring and after the death of an offspring

\begin{tabular}{lcc}
\hline Female name & $\begin{array}{c}\text { IBI after weaning an infant in } \\
\text { months (dates from } 1 \text { birth to } \\
\text { the next) }\end{array}$ & $\begin{array}{c}\text { IBI after death of unweaned infant } \\
\text { (dates from the loss of the previous } \\
\text { infant to the next birth) }\end{array}$ \\
\hline MA & $12(1 / 89-1 / 90)$ & $13(2 / 91-3 / 92)$ \\
& $12(1 / 90-1 / 91)$ & \\
& $32(3 / 92-11 / 94)$ & $44(8 / 96-1 / 00)$ \\
GF & $36(11 / 94-11 / 97)$ & $14(4 / 95-7 / 96)$ \\
Average & $14(11 / 93-1 / 95)$ & $23.7 \pm 17.6 \mathrm{mo}$ \\
\hline
\end{tabular}

Data on births before 1991 are from Homburg (1997).

\section{Female Reproduction: Maturation}

We observed 1 infant female (KL) for $\geq 2 \mathrm{mo} / \mathrm{yr}$ from birth (November, 1993) to reproductive maturity. We evaluated fecal steroids via estrone conjugate $\left(\mathrm{E}_{1} \mathrm{C}\right)$ and pregnanediol-3-glucuronide $(\mathrm{PdG})$ beginning in the subject's 3rd year. We documented the occurrence of irregular cycles in the wet season of 1997 (June 25-August 10) when she was $3.7 \mathrm{yr}$ old (Fig. 5a). We noted estrone conjugate peaks from isolated samples, but PdG showed no evidence of luteal activity taken as characteristic of ovarian cyclicity. She was cycling regularly by the following dry season (Fig. 5b), demonstrating the 17-d cycle documented for captive white-faced sakis (Savage et al., 1992; Shideler et al., 1994). The following wet season (in 1998), at ca. $4.7 \mathrm{yr}$, she engaged in aggressive interactions with the eldest female in the group (Table IV, and see later). Though we did not witness the resolution of the conflict, both females were still members of the main group the following summer (1999). KL birthed her first known infant in April, 2000 at $6.4 \mathrm{yr}$. In comparison, her mother (GF) was ca. 4 yr old when KL was born (Fig. 2).

Table III. Seasonality in infant births and deaths

\begin{tabular}{lcc}
\hline \multicolumn{1}{c}{ Season } & Births & Deaths \\
\hline Early wet & 1 & 2 \\
Late wet & 0 & 1 \\
Total wet season & 1 & 3 \\
Early dry & 6 & 0 \\
Late dry & 3 & 3 \\
Total dry season & 9 & 3 \\
\hline
\end{tabular}

From 1990 to 2001 there were 10 births and 6 presumed or confirmed infant deaths. Periods are designated as early wet season (May to July), late wet season (August-October); early dry season (November-January), late dry season (February-April). 
MA's second daughter (CR) was born in 1992 and also matured during the study. She left the main group at about $3.5 \mathrm{yr}$ and remained peripheral until 2001. We were not able to collect fecal samples from her while she was separated from the main group and she had no surviving offspring during the study. During the summer of 2001, we found CR (at the age of $7.7 \mathrm{yr}$ ), in the main group with KL. MA and GF were peripheral females in 2001.

In summary, over $12 \mathrm{yr}, 1$ female (MA) gave birth to 5 known infants from 1989 to 1997. Four infants survived to adulthood. One of her daughters (GF) gave birth to 4 infants, only 1 of which was raised to maturity. MA's second daughter (CR) was not known to have given birth to any infants by the end of the study when she was $9 \mathrm{yr}$ old. MA's granddaughter (KL). gave birth to 1 known infant during the study, at $6.4 \mathrm{yr}$.

\section{Aggressive Behavior}

Aggressive behavior took 2 forms in the saki group: chasing between members of the main group and peripheral individuals, and intragroup dyadic interactions (Table IV). The latter did not result in peripheralization. Chasing was first evident in the 3rd year of observations (1993): the 2nd year when there were 4 adult males in the group. Aggression took the form of sex-specific, male displacement and chasing (Table V). Only males were involved in the chases. Chasing appeared to be the primary activity, though several behaviors preceded the chase, e.g., traveling high in the canopy, vigilance (slow, halting travel and looking around), neck-rubbing (scent-marking), sniffing branches, body shaking, urine washing of hands and feet, and a vocalization heard only in the context of seeing peripheral individuals. The vocalization became our most reliable cue of an impending chase, but Buchanan et al. (1981) did not describe it in their list of white-faced saki vocalizations.

In 1993, sex-specific male huddles preceded chases which coincided with high male membership in the group. Huddles involved group ventralventral body contact with possible exchange of scent from the gular scent glands (Gleason, pers. com.; Homburg, 1997; Setz and Gaspar, 1997). After 1993 and a period of male-specific chasing, chases involved both males and females and occurred $c a$. once every $10 \mathrm{~h}$ of observation, i.e., almost daily (averaged over $5 \mathrm{yr}$ beginning in the 1993 observation period) (Table V). Chase distance averaged $218 \mathrm{~m}$, though we consider this a 


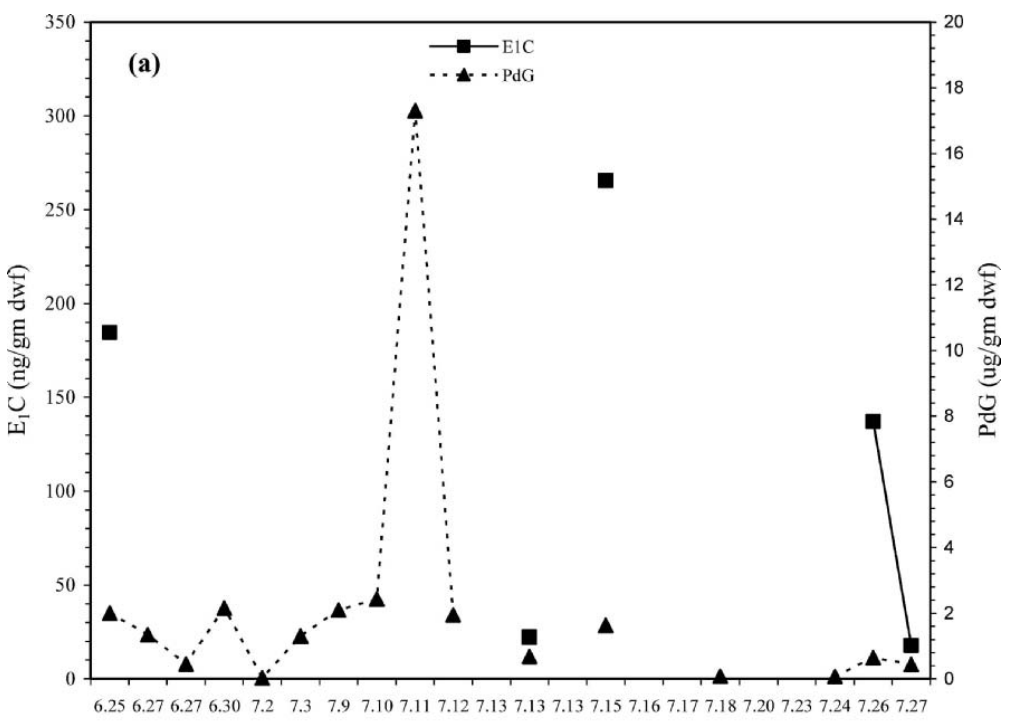

Sample date (1997)

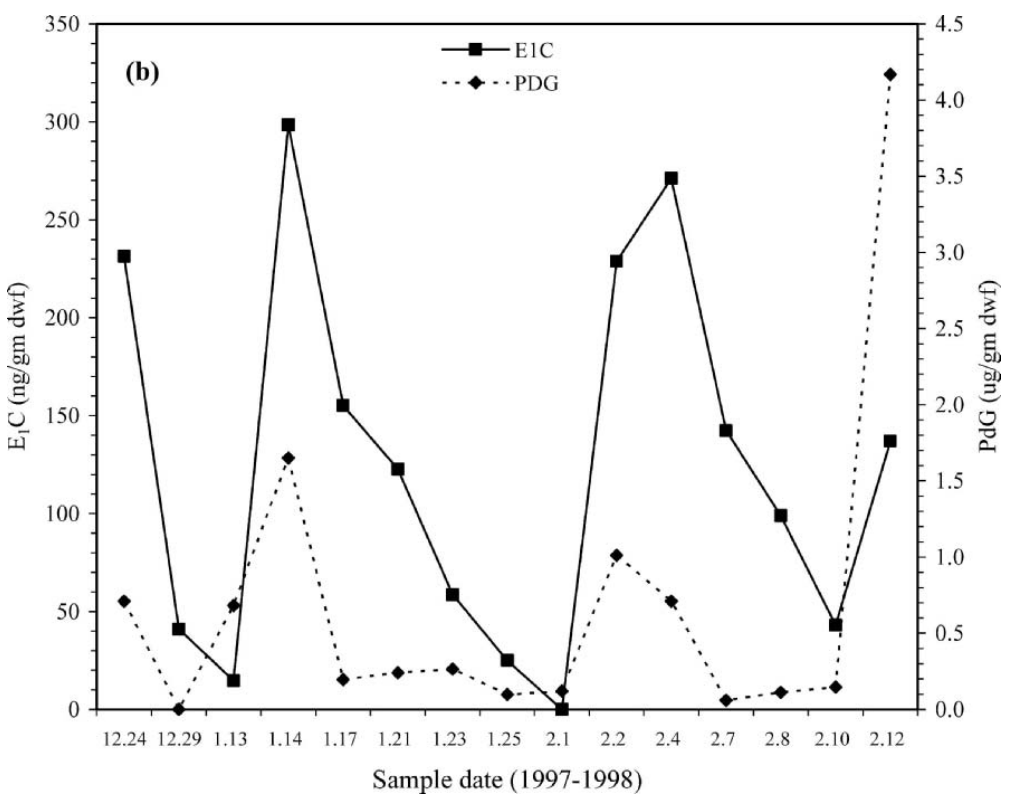

Fig. 5. Reproductive hormones documented in female KL showing no cyclical activity at age $3.6 \mathrm{yr}$ in 1997 (a), but regular cycles 6 mo later at age 4.1 (b). KL was $6.4 \mathrm{yr}$ old when she gave birth to her 1st known infant on April 9, 2000. $\mathrm{E}_{1} \mathrm{C}$ and PdG values expressed in dry weight of feces units (dwf). 
Table IV. Chronology of aggressive interactions

\begin{tabular}{|c|c|c|c|}
\hline Year & $\begin{array}{l}\text { Recipient(s) } \\
\text { of aggression }\end{array}$ & Aggressor(s) & $\begin{array}{l}\text { Behaviors documented between aggressors } \\
\text { and recipients of aggression }\end{array}$ \\
\hline 1993 & $\mathrm{BF} 0^{7}$ & $\begin{array}{l}\text { All } \sigma^{7} \sigma^{7}: \mathrm{WL}, \mathrm{JR}, \\
\text { SR, BD }\end{array}$ & $\begin{array}{l}\text { Coordinated chases preceded by body } \\
\text { contact (hugging) among aggressors. The } \\
\text { oldest male (BD) engaged in prechase } \\
\text { activities, but not chases. (SR found dead } \\
\text { in } 1994 \text {.) }\end{array}$ \\
\hline 1993 & $\mathrm{GF} q$ & none & $\begin{array}{l}\text { Not traveling with main group, but not } \\
\text { observed to have been chased }\end{array}$ \\
\hline 1994 & $\mathrm{BD} \sigma^{x}$ & WL $\sigma^{x}$ & $\begin{array}{l}\text { Dyadic interactions, not chases (staring by } \\
\text { WL; gaze aversion, pawing branches by } \\
\text { BD). (WL disappeared in 1995.) }\end{array}$ \\
\hline $\begin{array}{r}1995 \text { to } \\
2000\end{array}$ & $\mathrm{JR} \sigma^{\top} ; \mathrm{CR}+$ & $\begin{array}{l}\text { Group (primarily } \\
\mathrm{BF} \diamond^{7} \& \mathrm{GF} q \text { ) }\end{array}$ & $\begin{array}{l}\text { Chases began upon seeing JR or CR. A } \\
\text { member of the group giving a } \\
\text { characteristic vocalization. JR and CR } \\
\text { were chased for }>200 \mathrm{~m} \text { (average) and } \\
\text { appeared to be chased until they were out } \\
\text { of sight (see Table V). }\end{array}$ \\
\hline 1998 & MA ㅇ & $\mathrm{KL}$ q & $\begin{array}{l}\text { Dyadic interactions involving short chases to } \\
\text { the ground, body contact involving } \\
\text { tumbling and biting about the head and } \\
\text { ears drawing blood. MA did not leave the } \\
\text { group, but followed the group at some } \\
\text { distance. MA's 4-yr-old son (TX) was } \\
\text { observed to place himself in between KL } \\
\text { and MA during } 1 \text { such encounter. } \\
\text { Observations in the following year (1999) } \\
\text { documented that both KL and MA were } \\
\text { still members of the main group and } \\
\text { aggression has ceased. }\end{array}$ \\
\hline 2000 & $\begin{array}{l}\mathrm{JR} \sigma^{7} ; \mathrm{CR}_{+} \\
\mathrm{GF} \%\end{array}$ & $\begin{array}{l}\text { } ९ \text { MA \& KL, } \sigma^{\pi} \sigma^{\pi} \\
\text { BF \& TX }\end{array}$ & $\begin{array}{l}\text { Chases as described above; particularly } \\
\text { intense between MA and GF (GF was } \\
\text { chased to the ground by MA, but without } \\
\text { known bodily harm to GF.) }\end{array}$ \\
\hline 2001 & $\begin{array}{l}\text { JR ơ; } \mathrm{MA} q \\
\mathrm{GF} ;\end{array}$ & $\begin{array}{l}\text { ㅇ CR \& KL, } 0^{7} \sigma^{x} \\
\text { BF \& TX }\end{array}$ & Chases as described above (1995-2000). \\
\hline
\end{tabular}

Forms of aggression: 1 ) chasing, often by the entire main group against 1-3 individuals that became peripheral to the main group and 2) dyadic aggression between same-sexed individuals. In the first case, peripheral individuals were always chased by main group individuals.

minimum estimate because it was not always possible to maintain visual contact with individuals over the entire length of the chase.

The second form of aggressive interindividual behavior, dyadic interactions, differed from chases in both the quality of the interactions and the outcome. Dyadic aggression was sex-specific and directed at the oldest individuals by a younger male or female (Table IV). They were resolved without either individual leaving the group, but the aggressive interactions were 
Table V. Quantitative characteristics of chases

\begin{tabular}{lllccc}
\hline Year & $\begin{array}{c}\text { No. of } \\
\text { chases/day }\end{array}$ & $\begin{array}{c}\text { No. of } \\
\text { chases/h }\end{array}$ & $\begin{array}{c}\text { Minimum chase } \\
\text { distance }(\mathrm{m})\end{array}$ & $\begin{array}{c}\text { Total number of } \\
\text { chases observed }\end{array}$ & $\begin{array}{c}\mathrm{h} \text { of } \\
\text { observation }\end{array}$ \\
\hline 1993 & 1.0 & 0.13 & $182 \pm 64.6$ & 5 & 45.3 \\
1996 & 0.3 & 0.03 & 410 & 1 & 59.0 \\
1997 & 0.8 & 0.09 & $326.7 \pm 206.3$ & 9 & 84.7 \\
1998 & 1.6 & 0.20 & $204.9 \pm 113.7$ & 13 & 72.5 \\
1999 & 0.6 & 0.07 & $165.1 \pm 101.6$ & 14 & 195.4 \\
2000 & 0.7 & 0.09 & $211.8 \pm 95.2$ & 14 & 157.6 \\
Avg & $0.9 \pm 0.4$ & $0.1 \pm 0.04$ & $218.1 \pm 63.5$ & & \\
\hline
\end{tabular}

In all cases, members of the main group chased members of the peripheral individuals.

more intense than the chases, occurring multiple times a day and involving contact aggression.

In summary, we observed 2 variations of interindividual aggression during the $12 \mathrm{yr}$ of samples. After 1993, chases became a permanent and relatively predictable form of aggression that appeared to keep some individuals out of the main group. The relative proportion of subjects in the main group to peripheral individuals declined in the last years of the study, but we never observed peripheral individuals chasing members of the main group. Two females and 2 males were young adults when they were peripheralized from the group. All but 1 individual (JR) were eventually reintegrated into the main group. At the end of the study, there was a reversal of females-the female (CR) that had been outside the group for $5 \mathrm{yr}$ replaced the 2 oldest females (MA and GF). Aggressive interactions of the dyadic type were qualitatively different from chases because they did not result in expulsion from the group. Younger individuals targeted older individuals, but the older victims appeared to be unwilling to leave the group, even in the face of intense aggression.

\section{DISCUSSION}

Many unresolved issues remain regarding the social and sexual behavior of wild white-faced sakis. While recognizing the inherent problems associated with a study on a small island, it should also be acknowledged that free-ranging groups of Pithecia spp. have not yet been successfully habituated and no long-term studies of social behavior have been possible. At the very least, this study provides a long-term perspective on a wild group of sakis with observations taking the form of predictions: 1) there may be an upper limit of group size or an upper limit in the number of adult males in a group, i.e., a larger group size than would be expected from pair-bonded 
primates with tolerance of $\geq 2$ adult males and breeding females in a group; 2) both males and females disperse from the natal group; 3 ) dispersal is not age-limited, but may occur beginning at $c a$. $3.5 \mathrm{yr}$;) intergroup aggression takes the form of chasing, but also includes a variety of behaviors, i.e., scent marking, vigilance, body shaking, and loud whistle-like vocalizations; 5) males may be more willing to engage in intertroop encounters than females (but the criteria individuals use to undertake chases are still unclear); and 6) younger individuals may try to replace older individuals as group members via directed aggression.

If upheld, these predictions regarding defense of space would place Pithecia spp. closer to titis (Callicebus spp.) than the larger groups of multimale, multifemale, nonterritorial bearded sakis (Chiropotes spp.) and uakaris (Cacajao spp.) (Ayres, 1981, 1986; Boubli, 1999; Mason, 1968).

Reports are still widely disparate on white-faced saki home range size. Data of Vié et al. (2001) and Soini (1986) indicate a 10-fold difference in estimates of home range size for Pithecia pithecia and $P$. hirsuta, respectively. Also, Norconk et al. (2003) reported a home range size of 10.8 ha for 1 group of Pithecia pithecia in Suriname.

White-faced sakis are clearly different from titis in the intensity of bonds that exist between adult males and females; e.g., Kinzey (1981), Kinzey and Robinson (1983), Mason (1968), and Menzel (1986, 1993) reported tail-twining and vocal duets in Callicebus spp. Norconk and DeGama-Blanchet (2004) found adult male sakis to be closer to each other than either male was to females, which contrasts with the well studied, intense social bonds that characterize titi adults (Mason and Mendoza, 1998). Finally, adult male saki involvement in infant care appears to be minimal compared with that of titis (Mason, 1971; Mendoza and Mason, 1986a,b).

Hershkovitz (1987a) placed Pithecia spp. at the base of the saki-uakari clade, citing their relatively small body size and size-correlated morphological traits, but some characteristics of their social behavior also appear to be primitive relative to those of bearded sakis and uakaris and more similar to their sister group, the titis. While Pithecia spp. share dental features and predispersal seed predation with Chiropotes and Cacajao, they live in smaller social units that appear to be aggressive to each other. Thus, group size and the use of space appear to be unrelated to the feeding strategy that characterizes all species of the saki-uakari clade. Even this statement is probably an overgeneralization given the paucity of data on wild, free-ranging Pithecia spp., i.e., it is premature to generalize to all Pithecia spp. on the basis of data from P. pithecia. Hershkovitz (1987a) and Marriog and Cheverud (2004) recognized that there are differences in 
body size and anatomical features between the Pithecia and Monacha spp. that could well extend to differences in grouping patterns and habitat use.

Savage et al. $(1992,2002)$ defined reproductive parameters for captive white-faced saki females. A 17-d estrous cycle was documented in wild sakis and the 21-mo IBI Shideler et al. (1994) documented for captive sakis identical to we calculated for the wild sakis (average of $21.2 \mathrm{mo}$, range $12-36 \mathrm{mo}$ ). The minimum IBI is comparable to platyrrhines of similar body mass: Aotus, Saimiri, and Callicebus (12-15 mo: Fernandez-Duque et al., 2002; Kappeler and Pereira, 2003; Mason, 1971; Williams and Abee, 2003), but assuming that we were able to document most of the births during the study, an average of nearly $2 \mathrm{yr}$ is comparable to IBI of some of the larger bodied platyrrhines (Chiropotes satanas: Peetz, 2001; Cebus apella: DiBitetti and Janson, 2001, Cebus capucinus: Fedigan and Rose, 1995) and well within the IBI range for several populations of howlers (Fedigan and Rose, 1996; Glander, 1980; Kinzey, 1997) Pithecia pithecia female body mass $(1.35-1.88 \mathrm{~kg})$ (Hershkovitz, 1987a) is slightly larger than the 1st group (Aotus, Saimiri, and Callicebus) and $\geq 1 \mathrm{~kg}$ smaller than in the 2nd group (Chiropotes, Cebus, and Alouatta). In these respects, Pithecia spp. seem to bridge smaller- and larger-bodied platyrrhines.

Age at first birth in wild white-faced sakis ranged from 4 to $6 \mathrm{yr}$, $\geq 1 \mathrm{yr}$ longer than estimates from captivity, which are ca. $3 \mathrm{yr}$ (Savage et al., 1992) though there was considerable variation among wild females. The female age at maturation for the Guri Lake group places Pithecia between Saimiri, and the Atelinae, Cebus spp. (DiBitetti and Janson, 2001; Fedigan and Rose, 1995; Kappeler and Pereira, 2003; Williams and Abee, 2003). Finally, there was a strong bias toward dry season births as in other platyrrhines (Alouatta palliata: Fedigan and Rose, 1994; Ateles geoffroyi: Milton, 1981; Fedigan and Rose, 1994; Brachyteles arachnoides: Strier, 1996; Cebus capucinus: Fedigan and Rose, 1994; Chiropotes satanas: Peetz, 2001; Lagothrix lagothricha: Nishimura, 2003).

Though inbreeding cannot be causally related to any of the deaths that occurred during the study, the stochastic effects of small group size are apparently taking a toll on the ability to maintain a stable breeding group on the island. All 5 infants born in 1995-2000 died, albeit from a variety of causes. All of the infants were born to females in the main group even though there were long-term heterosexual units peripheral to the main group. At the end of the study, the island population consisted of 2 small groups: 1 of 4 adults and another of 3 adults.

Fuentes (1999) examined a wide range of primates characterized as monogamous-living in nuclear families. We have clarified that some of 
the parameters that Fuentes used to assess the monogamy package do not appear to characterize white-faced sakis. As he noted, Pithecia spp. do not live in exclusive 1-male/1-female groups and, given the number of surveys in addition to a few long-term studies, there is considerable variation in group size. We could identify no pair-bond reinforcement behavior in sakis; instead there was $\geq 1$ female and male of breeding age in the group. While we cannot evaluate the question of mate fidelity without paternity data, as many as 3 females were either cycling or pregnant at the same time and lived in a group with $>1$ adult male. We can confirm that adult males play an indirect role in infant care, and present the first data on interindividual aggression that may bear on dispersal patterns and territorial behavior. White-faced sakis are perhaps characterized best as living in small family units, which with long-term studies on free-ranging sakis may also be characterized as territorial groups in which both male and female offspring disperse.

\section{ACKNOWLEDGMENTS}

The study began under the direction of the late Warren G. Kinzey. I am very grateful for his guidance and leadership in the early years of the study and for the participation of numerous students in various projects during the study: Rebeca Araya, Nic Blanchet, Jason Brush, Courtney Buzzell, Natalia Ceballos, Elena Cunningham, Karla Funk, Terry Gleason, Brian Grafton, Amy Harrison Levine, Ingo Homburg, Pia Parolin, Angela Peetz, Mailén Riveros, Michelle Schenck, Bernardo Urbani, Suzanne Walker and colleagues Susan Shideler, Nancy Conklin-Brittain, Ken Glander, Molly Glander, and Tracy Frampton. The study depended on extensive Venezuelan personnel and logistical support from Estudios Básicos, EDELCA-Guri led by TSU Luis Balbás, the late Quique Pacheco, Martin Lubin, Asterio Farfán, and friends in Venezuela, particularly Clemensia Rodner of the Venezuelan Audubon Society, Angelica and Alfonso Vega, and botanist Gerardo Aymard (UNELLEZ, Edo. Portugesa). Financial support was provided by the National Science Foundation BNS 90-20614 to W. G. Kinzey and M. A. Norconk; SBR 98-07516 to M. A. Norconk, Wenner-Gren Foundation for Anthropological Research No. 6138 to M. A. Norconk, Research Foundation of the City University of New York to W. G. Kinzey, and Research and Graduate Studies of Kent State University to M. A. Norconk. I am especially grateful to Natalia Ceballos, Elena Cunningham, Terry Gleason, Susan Shideler, and 2 anonymous reviewers for commenting on earlier drafts of the manuscript. 


\section{REFERENCES}

Altmann, J. (1974). Observational study of behavior: Sampling methods. Behaviour 49: 227267.

Alvarez, E., Balbás, L., Massa, L., and Pacheco, J. (1986). Aspectos ecológicos del Embalse Guri. Interciencia 11: 325-333.

Aymard, G., Norconk, M., and Kinzey, W. (1997). Composición florística de comunidades vegetales en islas en el Embalse de Guri, Rio Caroní, Estado Bolívar, Venezuela, BioLlania Edición Esp. No. 6: 195-233.

Ayres, J. M. (1981). Observações sobre a ecologia e o comportamento dos cuxiús (Chiropotes albinasus e Chiropotes satanas, Cebidae: Primates), MA thesis, Fundação Universidade do Amazonas (FUA), Manaus, Brasil.

Ayres, J. M. (1986). Uakaris and Amazonian Flooded Forest, PhD dissertation, Cambridge University, Cambridge, UK.

Boubli, J. (1999). Feeding ecology of black-headed uacaris (Cacajao melanocephalus melanocephalus) in Pico de Neblina National Park, Brazil. Int. J. Primatol. 20: 719-729.

Brush, J. A. (2000). Sleeping Ecology of White-Faced Saki Monkeys in Lago Guri, Venezuela. 1-86. 2000, MA thesis, Kent State University, Kent, OH.

Brush, J. A., and Norconk, M. A. (1999). Early behavioral development in a wild white-faced saki monkey (Pithecia pithecia). Am. J Phys. Anth. (Suppl. 28), 99.

Buchanan, D. B., Mittermeier, R. A., and van Roosmalen, M. G. M. (1981). The saki monkeys, genus Pithecia. In Coimbra-Filho, A. F., and Mittermeier, R. A. (eds.), Ecology and Behavior of Neotropical Primates, Academia Brasileira de Ciências, Rio de Janeiro, pp. 391-417.

Buzzell, C. A., and Brush, J. A. (2000). Ontogeny of independence in wild and captive whitefaced saki monkeys (Pithecia pithecia). Am. J. Primatol. 51(Suppl. 1), 49-50.

Ceballos, N. (1996). Comportamiento social de una tropa de mono viudo Pithecia pithecia (Cebidae: Primates) en una isla del Embalse de Guri (Estado Bolívar). Licenciado en Biología, Universidad Central de Venezuela, Caracas.

Cunningham, E. P. (2003). The Use of Memory in Pithecia pithecia's Foraging Strategy, PhD dissertation, City University of New York.

CVG-EDELCA (Corporación Venezolana de Guayana, Electrificación del Caroní (1997). Guri, "Raul Leoni" Hydroelectric Central, CVG-EDELCA, Caracas, Venezuela.

DiBitetti, M. S., and Janson, C. H. (2001). Reproductive socioecology of tufted capuchins (Cebus apella) in northeastern Argentina. Int. J. Primatol. 22: 127-142.

Fedigan, L., and Rose, L. (1995). Interbirth intervals in three sympatric species of Neotropical monkey. Am. J. Primatol. 37: 9-24.

Fernandez-Duque, E., Rotundo, M., and Ramirez-Llorens, P. (2002). Environmental determinants of birth seasonality in night monkeys (Aotus azarai) of the Argentinean Chaco. Int. J. Primatol. 23: 639-656.

Freese, C. H., Heltne, P. G., Castro, N. R., and Whitesides, G. (1982). Patterns and determinants of monkey densities in Peru and Bolivia, with notes on distributions. Int. J. Primatol. 3: 53-90.

Fuentes, A. (1999). Re-evaluating primate monogamy. Am. Anthropol. 100: 890-907.

Glander, K. (1980). Reproduction and population growth in free-ranging mantled howler monkeys. Am. J. Phys. Anth. 53: 25-36.

Harrison, A. L. (1998). Feeding Party Dynamics of White-Faced Sakis in Lago Guri, Venezuela, MA thesis, Kent State University, Kent, OH.

Hershkovitz, P. (1985). A preliminary taxonomic review of the South American Bearded Saki Monkeys genus Chiropotes (Cebidae, Platyrrhini), with the description of a new subspecies. Fieldiana (new series) no. 27, Field Museum of Natural History, Chicago, pp. 1-46.

Hershkovitz, P. (1987a). The taxonomy of South American sakis, genus Pithecia (Cebidae, Platyrrhini): A preliminary report and critical review with the description of a new species and a new subspecies. Am. J. Primatol. 12: 387-468. 
Hershkovitz, P. (1987b). Uacaries, New World monkeys of the genus Cacajao (Cebidae, Platyrrhini): A preliminary taxonomic review with the description of a new subspecies. Am. J. Primatol. 12: 1-53.

Hershkovitz, P. (1990). Titis, New World monkeys of the genus Callicebus (Cebidae, Platyrrhini): A preliminary taxonomic review. Fieldiana (new series) no. 55, Field Museum of Natural History, Chicago, pp. 1-109.

Heymann, E. W., Encarnación, C. F., and Canaquin Y., J. E. (2002). Primates of the Río Curaray, northern Peruvian Amazon. Int. J. Primatol. 23: 191-201.

Homburg, I. (1997). Ökologie and sozialverhalten einer gruppe von weissgesicht-sakis (Pithecia pithecia pithecia Linnaeus 1766) im Estado Bolívar, Venezuela, PhD dissertation, Universität Bielefeld, Germany.

Johns, A. (1986). Notes on the ecology and current status of the buffy saki, Pithecia albicans. Primate Conserv. 7: 26-29.

Kappeler, P. M., and Pereira, M. E. (2003). Primate Life Histories and Socioecology, The University of Chicago Press, Chicago.

Kinzey, W. G. (1981). The titi monkeys, genus Callicebus. In Coimbra-Filho, A. F., and Mittermeier R. A. (eds.), Ecology and Behavior of Neotropical Primates, Academia Brasileira de Ciências, Rio de Janeiro, pp. 241-276.

Kinzey, W. G. (1992). Dietary and dental adaptations in the Pitheciinae. Am. J. Phys. Anth. 88: 499-514.

Kinzey, W. G. (1997). Alouatta. In Kinzey, W. G. (ed.), New World Primates: Ecology, Evolution, and Behavior, Aldine de Gruyter, New York, pp. 174-185.

Kinzey, W. G., and Robinson, J. G. (1983). Intergroup loud calls, range size, and spacing in Callicebus torquatus. Am. J. Phys. Anth. 60: 539-544.

Lehman, S. M., Prince, W., and Mayor, M. (2001). Variations in group size in white-faced sakis (Pithecia pithecia): Evidence for monogamy or seasonal cogregations? Neotrop. Primates 9: 96-101.

Marroig, G., and Cheverud, J. M. (2004). Cranial evolution in sakis (Pithecia, Platyrrhini) I: Interspecific differentiation and allometric patterns. Am. J. Phys. Anth. 125: 266278.

Martin, L. B., Olejniczak, A. J., and Maas, M. C. (2003). Enamel thickness and mocrostructure in pitheciin primates, with comments on dietary adaptations of the middle Miocene hominoid Kenyapithecus. J. Hum. Evol. 45: 351-367.

Mason, W. A. (1968). Use of space by Callicebus groups. In Jay, P. C. (ed.), Primates: Studies in Adaptation and Variability, Holt, Rinehart and Winston, New York, pp. 200216.

Mason, W. A. (1971). Field and laboratory studies of social organization in Saimiri and Callicebus. In Rosenblum, L. A. (ed.), Primate Behavior, Academic Press, New York, pp. 107-137.

Mason, W. A., and Mendoza, S. P. (1998). Generic aspects of primate attachments: Parents, offspring and mates. Psychoneuroendocrinology 23: 765-778.

Mendoza, S. P., and Mason, W. A. (1986a). Parental division of labour and differentiation of attachments in a monogamous primate (Callicebus moloch). Anim. Behav. 34: 1336-1347.

Mendoza, S. P., and Mason, W. A. (1986b). Parenting within a monogamous society. In Else, J. G., and Lee, P. C. (eds.), Primate Ontogeny, Cognition and Social Behaviour, Cambridge University Press, Cambridge, pp. 255-266.

Menzel, C. R. (1986). An experimental study of territory maintenance in captive titi monkeys (Callicebus moloch). In Else, J. G., and Lee, P. C. (eds.), Primate Ecology and Conservation, Cambridge University Press, Cambridge, pp. 133-143.

Menzel, C. R. (1993). Coordination and conflict in Callicebus social groups. In Mason, W. A., and Mendoza, S. P. (eds.), Primate Social Conflict, State University of New York Press, Albany, NY, pp. 253-290.

Milton, K. (1981). Estimates of reproductive parameters for free-ranging, Ateles geoffroyi, Primates 22: 574-579. 
Nishimura, A. (2003). Reproductive parameters of wild female Lagothrix lagotricha. Int. J. Primatol. 24: 707-722.

Norconk, M. A. (1996). Seasonal variation in the diets of white-faced sakis (Pithecia pithecia and Chiropotes satanas) in Guri Lake, Venezuela. In Norconk, M. A., Rosenberger, A. L., and Garber, P. A. (eds.), Adaptive Radiations of Neotropical Primates, Plenum, New York, pp. 403-423.

Norconk, M. A. (1997). Sakis, uakaris, and titi monkeys: Behavioral diversity in a radiation of seed predators. In Campbell, C. J., Fuentes, A., MacKinnon, K., Panger, M., and Bearder, C. (eds.), Primates in Perspective, Oxford University Press, Oxford, pp. 123-138.

Norconk, M. A., and Conklin-Brittain, N. L. (2004). Variation on frugivory: The diet of Venezuelan white-faced sakis. Int. J. Primatol. 25: 1-26.

Norconk, M. A., and DeGama-Blanchet, N. (2004). Male-male proximity suggests that sexspecific social preferences exist in Venezuelan white-faced sakis (Pithecia pithecia). Folia Primatol. 75 (Suppl 1): 313.

Norconk, M. A., and Grafton, B. W. (2002). Changes in forest composition and potential feeding tree availability on a small land-bridge island in Lago Guri, Venezuela. In Marsh, L.M. (ed.), Primates in Fragments, Kluwer Academic/Plenum, New York, pp. 211-227.

Norconk, M. A., Raghanti, M. A., Martin, S. K., Grafton, B. W., Gregory, L. T., and DiDijn, B. P. E. (2003). Primates of Brownsberg Natuurpark, Suriname, with particular attention to the pitheciins. Neotrop. Primates 11: 94-100.

Oliveira, J. M. S., Lima, M. C., Bonvincino, C., Ayres, J. M., and Fleagle, J. G. (2003). Preliminary notes on the ecology and behavior of the guianan saki (Pithecia pithecia, Linnaeus 1766; Cebidae, Primate), Acta Amazon. 15: 249-263.

Parolin, P. (1992). Characterization and Classification of the Vegetation in an Island of Lake Guri, Venezuela. MA thesis, University of Bielefeld, Germany.

Parolin, P. (1993). Forest inventory of an island in Guri Lake, Venezuela. In Barthlott, W., Naumann, C. M., Schmidt-Loske, K., and Schuchmann, K. L. (eds.), Animal-Plant Interactions in Tropical Environments, Bonn, Zoologiesches Forschungsinstitut und Museum Alexander Koenig, pp. 139-147.

Peetz, A. (2001). Ecology and social organization of the bearded saki Chiropotes satanas chiropotes (Primates: Pitheciinae) in Venezuela. In Schuchmann, K. L. (ed.), Ecotropical Monographs, No. 1, Society for Tropical Ecology, Bonn, Germany, pp. 1170.

Peres, C. A. (1993). Notes on the ecology of buffy saki monkeys (Pithecia albicans, Gray 1860): A canopy seed-predator. Am. J. Primatol. 31: 129-140.

Riveros, M. C. (1996). Dieta y comportamiento alimentario de una tropa de Pithecia pithecia (mono saki cara blanca), en una isla del Embalse de Guri, Edo. Bolívar. Licenciado en Biología, Universidad Central de Venezuela, Caracas.

Robinson, J. G., Wright, P. C., and Kinzey, W. G. (1987). Monogamous cebids and their relatives: Intergroup calls and spacing. In Smuts, B. B., Cheney, D. L., Seyfarth, R. M., Wrangham, R. W., and Struhsaker, T. T. (eds.), Primate Societies, The University of Chicago Press, Chicago, pp. 44-53.

Ryan, K. (1995). Preliminary report on social structure and alloparental care in Pithecia pithecia on an island in Guri Reservoir, Venezuela. Am. J. Phys. Anth. 20, 187.

Savage, A., Shideler, S. E., Moorman, E. A., Ortuño, A. M., Whittier, C. A., Casey, K. K., and McKinney, J. (1992). The reproductive biology of the white-faced saki (Pithecia pithecia) in captivity. Abstracts of the XIVth Congress of the International Primatological Society, pp. 59-60.

Savage, A., Zirofsky, D. S., Shideler, S. E., Smith, T. E., and Lasley, B. L. (2002). Use of levonorgestrel as an effective means of contraception in the white-faced saki (Pithecia pithecia), Zoo Biol. 21: 49-57.

Schneider, H., and Rosenberger, A. L. (1996). Molecules, morphology, and platyrrhine systematics. In Norconk, M. A., Rosenberger, A. L., and Garber, P. A. (eds.), Adaptive Radiations of Neotropical Primates, Plenum, New York, pp. 3-19. 
Setz, E. Z. F. (1993). Ecologia alimentar de um grupo de parauacus (Pithecia pithecia chrysocephala) em um fragmento florestal na Amazónia Central. PhD dissertation, Ciências Biológicas (Ecologia), Inst. Biol. UNICAMP, Campinas, SP, Brazil.

Setz, E. Z. F., and Gaspar, D. A. (1997). Scent-marking behaviour in free-ranging golden-faced saki monkeys, Pithecia pithecia chrysocephala. Sex differences and context, J. Zool. Lond. 241: 603-611.

Shideler, S. E., Savage, A., Ortuño, A. M., Moorman, E. A., and Lasley, B. L. (1994). Monitoring female reproductive function by measurement of fecal estrogen and progesterone metabolites in the white-faced saki (Pithecia pithecia). Am. J. Primatol. 32: 95-108.

Soini, P. (1986). A synecological study of a primate community in Pacaya-Samiria National Reserve, Peru, Primate Conserv. 7: 63-71.

Strier, K. B. (1996). Reproductive ecology of female muriquis (Brachyteles arachnoides). In Norconk, M. A., Rosenberger, A. L., and Garber, P. A. (eds.), Adaptive Radiations of Neotropical Primates, Plenum, New York, pp. 511-532.

Terborgh, J., Lopez, L., Tello, J., Yu, D., and Bruni, A. R. (1997). Transitory states in relaxing ecosystems of land bridge islands. In Laurance, W. F., and Bierregaard, R. O. (eds.), Tropical Forest Remnants: Ecology, Management, and Conservation of Fragmented Communities, The University of Chicago Press, Chicago, pp. 256-274.

Vié, J. C., Richard-Hansen, C., and Fournier-Chambrillon, C. (2001). Abundance, use of space, and activity patterns of white-faced sakis (Pithecia pithecia) in French Guiana. Am.J. Primatol. 55: 203-221.

Walker, S. E. (1996). The evolution of positional behavior in the saki-uakaris (Pithecia, Chiropotes, and Cacajao). In Norconk, M. A., Rosenberger, A. L., and Garber, P. A. (eds.), Adaptive Radiations of Neotropical Primates, Plenum, New York, pp. 335-367.

Williams, L., and Abee, C. (2003). Demographic analysis of the squirrel monkey breeding and research resource colony, 1982-2002. Am. J. Primatol. 60 (Suppl. 1), 40. 